\begin{tabular}{|c|c|}
\hline \multirow{3}{*}{ 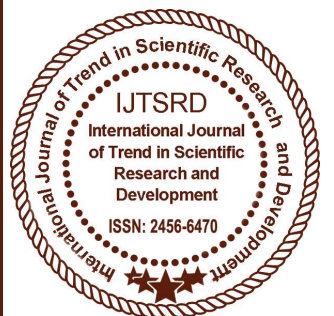 } & $\begin{array}{l}\text { International Journal of Trend in Scientific } \\
\text { Research and Development (IJTSRD) }\end{array}$ \\
\hline & International Open Access Journal \\
\hline & ISSN No: 2456 - 6470 | www.ijtsrd.com | Volume - 2 | Issue - 2 \\
\hline
\end{tabular}

\title{
An Empirical Analysis of Entrepreneurial Ecosystem in Selected Asian Countries
}

\author{
Neha Tiwari \\ Research Scholar, Department of Business Administration \\ University of Lucknow, Uttar Pradesh
}

\begin{abstract}
The positive relationship between entrepreneurship and economic development through employment generation and poverty reduction has been well established in academic research. This is the rationale why governments across different countries try to comprehend the dynamics of entrepreneurship. There is growing interest in decoding the context in which entrepreneurship thrives. Research on "Entrepreneurial Ecosystem" has gained momentum since it provides the necessary framework in which entrepreneurship develops. The objective of this study is to analyze the various components of entrepreneurial ecosystem and Total early stage entrepreneurial activity (TEA) in selected Asian countries. The research is based on secondary data related to entrepreneurial ecosystem and total early stage entrepreneurial activity, provided by Global entrepreneurship Monitor (GEM). The findings of the research indicate that there is need to improve the entrepreneurial ecosystem in Asian countries. Asian countries exhibit insufficient provisions of access to finance for entrepreneurs. Government policies and programs, taxes and bureaucratic regime are also insufficient for nurturing entrepreneurial environment. Entrepreneurship education and training both at basic school level and post school level are not sufficient for creating a conducive environment for

entrepreneurs. Markets, infrastructural provisions and social and cultural norms are also not found to be sufficient for entrepreneurship to thrive in Asian context. Total early stage entrepreneurial activity (TEA) is also quite low for Asian countries. The findings of the study can be of instrumental value for academicians and policy makers interested in entrepreneurship development in Asia.

Keywords: Entrepreneurship, Entrepreneurial ecosystem, Total early stage entrepreneurial activity (TEA), Global entrepreneurship Monitor (GEM)

\section{JEL CLASSIFICATION: L26}

\section{INTRODUCTION}

Entrepreneurship has an instrumental role in economic development of any country through promoting growth and prosperity (OECD, 2000, Schramm 2006a, and Baumol et al, 2007). Entrepreneurs lead to creation of markets and organizations (Spulber, 2008). This argument propels governments to focus on entrepreneurship development as a way of accelerating economic growth. The research pertaining to entrepreneurship in Asian countries has been summarized in Table I.
\end{abstract}


Table I: Research studies on entrepreneurship in Asia

\begin{tabular}{|l|l|}
\hline Researcher & Area of research \\
\hline Ang \& Hong, 2000; Chung \& Busenitz, 2001 & Factors affecting entrepreneurship \\
\hline Patra, 2002; Tan, 1999; Yu, 1998 & Profile of ventures \\
\hline Cook, 2001; Tashiro, 1999 & Access to finance \\
\hline Lee \& Chan, 1998; Imai \& Kawagoe, 2000; & Government policies \\
\hline $\begin{array}{l}\text { Gomez \& Hsin-Huang, 2001; Zapalska \& Edwards, 2001; } \\
\text { Sorenson, 2000; Cummings, 1996; Lam \& Paltiel, 1994; } \\
\text { Redding, 1990 }\end{array}$ & \\
\hline
\end{tabular}

Source: Review of Literature

Asia has an increasingly important role to play in the global context. Asia accounts for 40 percent of global economy and has consistently registered a growth rate of approximately 6 percent over the last 25 years. But there are surmounting challenges confronted by Asian countries. Asia is home to two-third of world's poor population ${ }^{i}$. Problems of income inequality are also on the rise. ii The answer to such problems may be found in promoting entrepreneurship and self employment.

\section{REVIEW OF LITERATURE}

\subsection{Entrepreneurial Ecosystem}

Context is widely studied in entrepreneurial domain (Ucbasaran et al., 2001; Welter, 2011; Zahra et al., 2014; Autio et al., 2014). The concept of entrepreneurial ecosystem started emerging in 1980's and 1990's, when the role of social, cultural and political factors was recognized as instrumental in entrepreneurship (Dodd \& Anderson, 2007). Research studies established the dominant role of regional and economic factors on entrepreneurial activity (Pennings 1982, Dubini 1989, Van de Ven 1993 and Bahrami and Evans 1995). The aspects defining entrepreneurial ecosystem have been summarized in Table II

\section{Table II: Literature review on entrepreneurial ecosystem}

\section{Researcher}

\section{Definition}

Herrington, M., \& Kew, P. Consist of entrepreneurial framework conditions that provide necessary (2017). GEM 2016/17 global support for creation and growth of new firms. report.

Zeger Van de Wiele (2017)

"Entrepreneurial ecosystem refers to intertwined elements within a specific region ,individual and combined interaction between those elements will entrepreneurship in that region".

Stam, E., \& Spigel, B. (2016)..

"A set of interdependent actors and factors coordinated in such a way that they enable productive entrepreneurship within a particular territory".

Mason, C., \& Brown, R. (2014).

"A set of interconnected entrepreneurial actors, organizations, institutions and processes which formally and informally interact to connect, mediate and govern the performance within the local entrepreneurial environment".

Foster, G., Shimizu, C., Eight pillar of entrepreneurial ecosystem are: Accessible markets, Human Ciesinski, S., Davila, A., Capital Workforce, Funding and Finance, Mentors Advisors Support Hassan, S., Jia, N., \& Morris, R. Systems, Regulatory Framework and Infrastructure, Education and Training, (2013, September).

Vogel (2013, p. 446)

Major Universities as Catalysts, Cultural Support

"An interactive community of different and interdependent factors and actors within a geographic region, which develop over time and whose actors and factors coexist and interact to entrepreneurship". 
Isenberg, D. (2011).

Six domains within the entrepreneurial system: a conducive culture, enabling policies and leadership, availability of appropriate finance, quality human capital, venture friendly markets for products, and a range of institutional supports

Source: Review of Literature

Different dimensions of entrepreneurial ecosystem considered in this study are (Herrington, M., \& Kew, P. (2017). GEM 2016/17 global report):

1. Entrepreneurial Finance: Availability of both equity and debt finance to entrepreneurs.

2. Government Policy: Support offered through public policies to entrepreneurs. The two sub components are:

a) Taxes and regulatory support available to entrepreneurs.

b) Consideration of entrepreneurship as a relevant economic issue.

3. Government Entrepreneurship Programs assisting small and medium enterprises.

4. Entrepreneurship Education has two sub components

\section{a) Entrepreneurship Education at basic school level. \\ b) Entrepreneurship Education at post- secondary levels}

5. R\&D Transfer. This is related to how easily outcomes of research and development transferred to small and medium enterprises.

\section{Commercial and Legal Infrastructure.}

7. Entry Regulation: Sub components are:

a) Market Dynamics: longitudinal changes in markets

b) Market Openness: free entry of new firms to enter existing markets.

8. Physical Infrastructure: pertains to availability of basic infrastructure for startups.

9. Cultural and Social Norms: This is related to the extent to which the prevalent social and cultural norms favor or hinder entrepreneurship.

\subsection{Entrepreneurial ecosystem in selected Asian countries}

Numerous research studies have cited insufficiency of entrepreneurial framework conditions in Asian countries. In china lack of formal financing (Cong, 2009), weaker property rights, high government interference (Young et al., 2008) and cumbersome approvals by governments (Reynolds, 1982) often constrain entrepreneurship. In Georgia institutional, systemic and social constraints hinder entrepreneurship development (Rudaz, P, 2012).

Simplifying tax regime, improving access to finance for Small \& Medium Enterprises, promoting Foreign Direct Investments and Research \& Development transfer, increasing focus on skill development and improvement in ease of doing business is desired for entrepreneurship development in Georgia (Kuriakose, S. (Ed.), 2013.). Access to formal finance is a challenge for entrepreneurs in Hong Kong but ease of doing business is fairly high with promising infrastructure and tax regime conducive for entrepreneur (Chua, B. L., 2003).

In India, Social, technological, financial and policy challenges discourage entrepreneurs( Santhi, N., \& Kumar, S. R. ,2011) Lack of promising infrastructure is a hurdle for entrepreneurs to grow and governments are keenly promoting entrepreneurship through "Make in India", "Start up India", "ASPIRE" Schemes (Sunita, S., \& Srija, A., 2016). The policy imperatives for entrepreneurship development in Indian context include boosting infrastructure, devising a comprehensive framework for promotion of entrepreneurship, facilitating access to credits, markets and resources (Shah, H., 2013).

In Indonesia, cultural norms do not favor entrepreneurship but government is keen on promoting entrepreneurship "iii. According to "Report on entrepreneurship initiatives in APO economies" unsupportive tax regime and government policy hinder entrepreneurial activity in Indonesia and policy addressing these constraints is desired. In Lebanon, culture is supportive of entrepreneurs and government identifies Small \& Medium Enterprises as drivers of growth (Ahmed et al., 2012). In Malaysia policy towards entrepreneurs need to be more proactive. Coordination between government, private sector and entrepreneurs is desirable (Ariff, M., \& Abubakar, S. Y. , 2002). State led initiatives in Malaysia are active in promoting entrepreneurship (Abdullah, S., \& Muhammad, A., 2008).

Access to finance, risk aversion, fear of failure, market and knowledge barriers, stress avoidance, and reluctant attitude towards change are dominant challenges encountered by entrepreneurs of Qatar (Boumediene Kebaili, et al, 2015). According to 
"Qatar National Development Strategy 2011-16" the government is aggressively focusing to create a conducive environment for entrepreneurs.

In Saudi Arabia there is need to focus on entrepreneurial education to sustain a culture supportive for entrepreneurship (Yusuf, N., \& Albanawi, N. I., 2016). Government of Saudi Arabia is keen on promoting entrepreneurship. The country is making its environment favorable for entrepreneurs to grow (Kayed and Hassan, 2013). Entrepreneurship is now fuelling economic growth in Saudi Arabia (Faria, et al, 2010). In Taiwan there is a need of better entrepreneurship education, systematic campaigns to increase awareness about entrepreneurship, need of entrepreneurship skills and need of infrastructural development (Tseng, C., 2012). In Thailand lack of financial support, government policies and inappropriate educational system hinder entrepreneurship development (GEM Thailand 2013 report, Paulson, A. L., 2008). In Turkey, government reforms, business legislations and societal views about entrepreneurship needs to be changed (Tracy, M., 2013).

According to the Report on "The Role of Government in Supporting Entrepreneurship \& SME Development "by Mohammed Bin Rashid Establishment For SME Development DUBAI SME 2011, U.A.E Federal government is keen on promoting entrepreneurship through lowering cost of doing business and creating a policy environment that is conducive to entrepreneurship development. U.A.E is in leading country in global competitiveness as per world economic forum (Schwab, 2013). Major barriers to entrepreneurship are: access to finance, lack of entrepreneurial skills and cumbersome administrative procedures (El-Sokari et al., 2013, pp.47-48). The entrepreneurs expect government of U.A.E to chart measures which help in fighting bureaucracy and cutting red tape; ensuring business confidentiality and trade secrets; aligning student curricula in the education system with the needs of business (Edelman, 2014).

\section{RESEARCH METHODOLOGY}

The research is exploratory and quantitative in approach. The major objectives of the research are

- To analyze the various components of entrepreneurial ecosystem in selected Asian countries
- To analyze Total early stage entrepreneurial activity (TEA) in selected Asian countries

The study is based on secondary sources of data. The data is retrieved from Global entrepreneurship monitor (GEM) data pertaining to Entrepreneurial framework conditions .The Global entrepreneurship monitor (GEM) compiles data about Entrepreneurial framework conditions through national expert survey $^{\text {iv }}$. The data is collected through a scale where 1 denotes highly insufficient and 9 denotes highly sufficient. Total early stage entrepreneurial activity (TEA) data is compiled from Global entrepreneurship monitor (GEM), Global report 2016-17.

\section{DATA ANALYSIS AND FINDINGS}

The data pertaining to dimensions of entrepreneurial ecosystem has been retrieved from Global entrepreneurship Monitor (GEM) database on entrepreneurial framework conditions. The data is collected through a national expert survey on a scale of 1 to 9.1 denotes highly insufficient and 9 denotes highly sufficient. The data related to Total Early Stage entrepreneurial activity is retrieved from Global entrepreneurship Monitor (GEM) Global Report 2016-17. The data has been compiled in Table III.

\subsection{Country wise performance on components of entrepreneurial ecosystem}

The analysis brought forth following key findings:

Entrepreneurial Finance: Access to finance is most sufficiently available in India among the Selected Asian countries with mean value of 3.43 . Access to finance is most insufficiently available to entrepreneurs in Iran with mean of 1.75.

Government support and policies: Government support and policies are most satisfactory in South Korea with mean of 3.56 and least satisfactory in Iran with mean value of 2 .

Taxes and bureaucracy: The taxes and bureaucratic environment is most sufficient for entrepreneurs in Hong Kong with mean of 4.18 and least sufficient in Iran with value of 1.62 .

Government programs for entrepreneurs: United Arab Emirates has most sufficient provisions of Government programs for entrepreneurs with mean value of 3.34 and Iran has most insufficient provisions with mean of 1.36 .

Basic school entrepreneurial education and training: Qatar has most sufficient provisions of entrepreneurial education and training at basic level of 
International Journal of Trend in Scientific Research and Development (IJTSRD) ISSN: 2456-6470

schooling with mean value of 2.7 and Saudi Arabia has most insufficient provisions with mean of 1.44.

Post school entrepreneurial education and training: Qatar has most sufficient provisions of education and training at post school level with mean of 3.46 and Iran has least sufficient provisions in this dimension with mean of 1.83 .

Research and development (R \& D) transfer: India has most sufficient provisions of R\& D transfer having mean vale of 2.49 each. Iran has least satisfactory provisions in this aspect with mean of 1.81 .

Commercial and professional infrastructure: United Arab Emirates has most sufficient availability of commercial and professional infrastructure with mean of 3.29 while Iran least sufficient provisions in this dimension with mean of 1.85 .

Internal market dynamics: China and South Korea have most sufficient internal market dynamics for entrepreneurs with mean of 4.24 each while Israel has least sufficient internal market dynamics with mean of 2.42 .

Internal market openness: Georgia has most sufficient internal market openness for entrepreneurs with mean of 3.01 and Iran has least sufficient provisions of internal market openness with mean of 1.63.

Physical and services infrastructure: Hong Kong has most sufficient provisions of physical and services infrastructure for entrepreneurs with mean of 4.8 and Lebanon has most insufficient physical and services infrastructure with mean of 2.24.

Cultural and social norms: Israel has most supportive social and cultural norms favoring entrepreneurship with mean of 4.29 and Iran has most unsupportive social and cultural norms for entrepreneurs with mean of 2.1 .

Total early stage entrepreneurial Activity (TEA) in the year 2016 was found to be highest in Lebanon with value of 21.2 and Malaysia had least TEA with value of 4.7 .

\section{Table III}

Data on Entrepreneurial Framework and T.E.A (Total early stage entrepreneurial activity)

\begin{tabular}{|l|l|l|l|l|l|l|l|}
\hline $\begin{array}{l}\text { Econom } \\
\text { y }\end{array}$ & Year & $\begin{array}{l}\text { Financing } \\
\text { for } \\
\text { entreprene } \\
\text { urs }\end{array}$ & $\begin{array}{l}\text { Governmen } \\
\text { tal support } \\
\text { and policies }\end{array}$ & $\begin{array}{l}\text { Taxes and } \\
\text { bureaucra } \\
\text { cy }\end{array}$ & $\begin{array}{l}\text { Governmen } \\
\text { tal } \\
\text { programs }\end{array}$ & $\begin{array}{l}\text { Basic school } \\
\text { entrepreneur } \\
\text { ial education } \\
\text { and training }\end{array}$ & $\begin{array}{l}\text { Post school } \\
\text { entrepreneur } \\
\text { ial education } \\
\text { and training }\end{array}$ \\
\hline China & 2016 & 3.32 & 3.14 & 2.89 & 2.66 & 2.04 & 3.17 \\
\hline Georgia & 2016 & 2.43 & 3.32 & 3.87 & 3.22 & 2.19 & 2.95 \\
\hline $\begin{array}{l}\text { Hong } \\
\text { Kong }\end{array}$ & 2016 & 2.92 & 3.24 & 4.18 & 3.15 & 1.82 & 2.81 \\
\hline India & 2016 & 3.43 & 3.34 & 2.61 & 2.82 & 2.4 & 3.01 \\
\hline Indonesia & 2016 & 2.77 & 2.77 & 2.27 & 2.46 & 2.48 & 3.45 \\
\hline Iran & 2016 & 1.75 & 2 & 1.62 & 1.36 & 1.46 & 1.83 \\
\hline Israel & 2016 & 2.73 & 2.1 & 1.97 & 2.37 & 1.92 & 2.91 \\
\hline Jordan & 2016 & 2.44 & 2.13 & 2.1 & 2.22 & 1.47 & 1.85 \\
\hline $\begin{array}{l}\text { Kazakhst } \\
\text { an }\end{array}$ & 2016 & 2.9 & 3.11 & 2.66 & 2.81 & 1.94 & 2.59 \\
\hline Lebanon & 2016 & 3.05 & 2.08 & 2.34 & 2.35 & 2.61 & 3.11 \\
\hline Malaysia & 2016 & 3.2 & 2.98 & 2.57 & 2.99 & 2.44 & 3.11 \\
\hline Qatar & 2016 & 2.67 & 3.25 & 2.84 & 3.23 & 2.7 & 3.46 \\
\hline $\begin{array}{l}\text { Saudi } \\
\text { Arabia }\end{array}$ & 2016 & 2.39 & 2.41 & 2.48 & 2.12 & 1.44 & 2.26 \\
\hline $\begin{array}{l}\text { South } \\
\text { Korea }\end{array}$ & 2016 & 2.45 & 3.56 & 2.79 & 3.21 & 1.99 & 2.42 \\
\hline Taiwan & 2016 & 2.84 & 2.63 & 2.7 & 3.01 & 2.4 & 2.64 \\
\hline Thailand & 2016 & 2.83 & 2.47 & 2.34 & 2.19 & 1.9 & 2.9 \\
\hline Turkey & 2016 & 2.8 & 2.68 & 1.82 & 2.26 & 1.68 & 2.9 \\
\hline U.A.E. & 2016 & 2.66 & 3.51 & 3.3 & 3.34 & 2.68 & 2.84 \\
\hline & & & & & & & \\
\hline
\end{tabular}


International Journal of Trend in Scientific Research and Development (IJTSRD) ISSN: 2456-6470

\begin{tabular}{|c|c|c|c|c|c|c|c|}
\hline $\begin{array}{l}\text { Econom } \\
\mathbf{y}\end{array}$ & $\begin{array}{l}\text { R\&D } \\
\text { transf } \\
\text { er }\end{array}$ & $\begin{array}{l}\text { Commercia } \\
\text { l and } \\
\text { professiona } \\
\text { I } \\
\text { infrastruct } \\
\text { ure }\end{array}$ & $\begin{array}{l}\text { Internal } \\
\text { market } \\
\text { dynamics }\end{array}$ & $\begin{array}{l}\text { Internal } \\
\text { market } \\
\text { openness }\end{array}$ & $\begin{array}{l}\text { Physical } \\
\text { and services } \\
\text { infrastructu } \\
\text { re }\end{array}$ & $\begin{array}{l}\text { Cultural and } \\
\text { social norms }\end{array}$ & TEA \\
\hline China & 2.49 & 2.58 & 4.24 & 2.66 & 4.33 & 3.47 & 10.3 \\
\hline Georgia & 2.07 & 2.83 & 3.21 & 3.01 & 4.19 & 3.37 & 8.6 \\
\hline $\begin{array}{l}\text { Hong } \\
\text { Kong }\end{array}$ & 2.45 & 3.14 & 2.99 & 2.78 & 4.8 & 2.87 & 9.4 \\
\hline India & 2.87 & 3.11 & 3.76 & 2.98 & 3.89 & 3.11 & 10.6 \\
\hline Indonesia & 2.49 & 2.4 & 3.99 & 2.35 & 3.14 & 3.24 & 14.1 \\
\hline Iran & 1.81 & 1.85 & 3 & 1.63 & 3.79 & 2.1 & 12.8 \\
\hline Israel & 2.63 & 3.13 & 2.42 & 2.12 & 3.69 & 4.29 & 11.3 \\
\hline Jordan & 2.28 & 2.86 & 3.11 & 2.27 & 3.8 & 2.52 & 8.2 \\
\hline $\begin{array}{l}\text { Kazakhst } \\
\text { an }\end{array}$ & 1.95 & 3.15 & 2.8 & 2.46 & 3.57 & 3.05 & 10.2 \\
\hline Lebanon & 2.41 & 3.2 & 2.65 & 2.28 & 2.24 & 3.67 & 21.2 \\
\hline Malaysia & 2.77 & 3.11 & 3.89 & 2.78 & 3.89 & 3.19 & 4.7 \\
\hline Qatar & 2.62 & 3.08 & 2.65 & 2.36 & 3.87 & 3.23 & 7.8 \\
\hline $\begin{array}{l}\text { Saudi } \\
\text { Arabia }\end{array}$ & 1.85 & 2.37 & 2.9 & 2.38 & 3.99 & 2.72 & 11.4 \\
\hline $\begin{array}{l}\text { South } \\
\text { Korea }\end{array}$ & 2.54 & $2.6)$ & 4.24 & 2.3 & 3.97 & 2.97 & 6.7 \\
\hline Taiwan & 2.79 & $2.78=$ & $3.68=T$ & $2.95 \mathrm{C}$ & 3.81 & 3.11 & 8.2 \\
\hline Thailand & 2.38 & $2.97=$ & 3.63 & 2.54 & 3.94 & 3.09 & 17.2 \\
\hline Turkey & 2.63 & 3.22 & Res & $2.43 \mathrm{C} \cap \mathrm{a}$ & 3.49 & 2.89 & 16.1 \\
\hline U.A.E & 2.55 & 3.29 & 3.44 & 3 & 4.25 & 3.69 & 5.7 \\
\hline
\end{tabular}

Source: GEM GLOBAL Report 2016-17

Table IV

Descriptive Statistics

\begin{tabular}{|c|c|c|c|c|}
\hline & Minimum & Maximum & Mean & Std. Deviation \\
\hline Financing for entrepreneurs & 1.75 & 3.43 & 2.7544 & .38966 \\
\hline Government support and policies & 2.00 & 3.56 & 2.8178 & .52472 \\
\hline Taxes and bureaucracy & 1.62 & 4.18 & 2.6306 & .65301 \\
\hline Governmental programs & 1.36 & 3.34 & 2.6539 & .52573 \\
\hline $\begin{array}{l}\text { Basic school entrepreneurial education and } \\
\text { training }\end{array}$ & 1.44 & 2.70 & 2.0867 & .42092 \\
\hline Post school entrepreneurial education and training & 1.83 & 3.46 & 2.7894 & .46239 \\
\hline R\&D transfer & 1.81 & 2.87 & 2.4211 & .31565 \\
\hline Commercial and professional infrastructure & 1.85 & 3.29 & 2.8706 & .38149 \\
\hline Internal market dynamics & 2.42 & 4.24 & 3.3500 & .56624 \\
\hline Internal market openness & 1.63 & 3.01 & 2.5156 & .36204 \\
\hline
\end{tabular}


International Journal of Trend in Scientific Research and Development (IJTSRD) ISSN: 2456-6470

\begin{tabular}{|l|l|l|l|l|}
\hline Physical and services infrastructure & 2.24 & 4.80 & 3.8139 & .52961 \\
\hline Cultural and social norms & 2.10 & 4.29 & 3.1433 & .47941 \\
\hline TEA & 4.70 & 21.20 & 10.8056 & 4.21977 \\
\hline
\end{tabular}

Source: Primary data analysis

\subsection{Cumulative Analysis of entrepreneurial ecosystem of Asian Region}

- The data was analyzed through descriptive statistics for assessing the entrepreneurial ecosystem of Asian Region. The details of descriptive analysis have been summarized in Table IV. As per the descriptive statistics following findings can be deciphered:

- Asia ranks poorly in terms of financing provisions for entrepreneurs with mean of 2.7544 .

- It is evident that government policies and programs are insufficient (Mean=2.8178) in Asia for entrepreneurship.

- Asia offers insufficient provisions on dimensions of taxes and bureaucratic environment (Mean= 2.6306).

- Asia has insufficient provisions of government programs for entrepreneurs (Mean=2.6539).

- Entrepreneurial education and training 0 is insufficient $($ Mean=2.0867) at basic school level in Asian countries.

- Entrepreneurial education and training at post school level is also insufficient in Asia $($ Mean=2.7894).

- There are insufficient mechanisms of R\&D transfer for entrepreneurs in Asia (Mean=2.4211).

- Asia offers insufficient commercial and professional infrastructure for entrepreneurs (Mean=2.8706).

- Asia has insufficient provisions of Internal market dynamics for entrepreneurs (Mean=3.3500).

- Asia has insufficient provisions of Internal market openness for entrepreneurs (Mean=2.5156).

- Asia offers insufficient Physical and services infrastructure for entrepreneurs (Mean=3.8139).

- Asia offers insufficient provisions of social and cultural norms for entrepreneurs (Mean=3.1433).

- The mean TEA for Asia is 10.8056 percent.

\section{CONCLUSIONS \& RESEARCH IMPLICATIONS}

It is evident from the results of analysis that the selected Asian countries in the study have insufficient framework conditions for nurturing entrepreneurship. The selected Asian countries have very limited total entrepreneurial stage activity. The limited entrepreneurial Activity can be attributed to insufficient entrepreneurial framework conditions. Lack of access to entrepreneurial finance, lack of market openness and inhibitory market dynamics and tax regime can hinder full participation of entrepreneurs in economic development. Cumbersome tax regime and insufficient government provisions for entrepreneurs can also thwart the development of entrepreneurship. Lack of infrastructure is another obstacle encountered by entrepreneurs in Asian countries. Cultural and social norms discouraging entrepreneurial mindset is another hindrance for potential and existing entrepreneurs of Asia. The findings of the research are instrumental for policy makers across Asian countries. The policy makers must devise strategies to create a conducive environment for entrepreneurship to develop.

Many Asian countries have now realized that entrepreneurship is vital to their economc development and are taking concrete measures to strengthen entrepreneurial ecosystem.. Government policies focus on privatization to nurture productivity and entrepreneurship (Doshi, 1994). United Nations Development Program (UNDP) and OECD have supported government efforts to promote entrepreneurial activity in Asia (UNDP, 2002). Most of the Asian countries are adopting market oriented policies that promote entrepreneurial activity in Asia (Dana, 1999). Entrepreneurs have undoubtedly played a key role in economic development of China (ADB, 2002). There have been positive effects of various government programs on promoting entrepreneurial activity (Anderson, 2002; Graham \& Manning, 2000; Mariotti, 1999; Owuala, 1999; Fadahunsi, 1991). The success of microfinance in the context of Bangladesh has been established (Qadir, 1999). Hong Kong is established to be more entrepreneurial (Yu, 2000)

Entrepreneurship is poised to grow since countries are taking concrete measures to create a conducive environment for women entrepreneurship. South Korea has invested \$ 30 Billion in establishing media 
valley to promote technology startups. Singapore is investing aggressively on infrastructure to promote startups. Hong Kong is aggressively focusing on deregulation and creating new markets. Malaysia is also keen on promoting investments in multimedia projects to promote new ventures. Indonesia is investing tremendously on education, agribusiness and labor intensive manufacturing. Thailand is focusing on improving education and lowering barriers to investments to fuel entrepreneurial growth (Richardson, J. 2004). Similar efforts are desirable in all Asian countries to realize the full potential of existing and prospective entrepreneurs.

\section{REFERNCES}

1. Abdullah, S., \& Muhammad, A. (2008). The development of entrepreneurship in Malaysia: State-led initiatives. Asian Journal of Technology Innovation, 16(1), 101-116.

2. Ahmed, Z. U., Zgheib, P. W., Kowatly, A. K., \& Rhetts, P. (2012). The history of overseas Lebanese entrepreneurs operating worldwide. Journal of Management History, Vol. 18, 295-311.

3. Anderson, Robert B. "Entrepreneurship and Aboriginal Canadians: A Case Study in Economic Development," Journal of Developmental Entrepreneurship, Vol. 7, No. 1, 2002.

4. Ang, S. H., \& Hong, D. G. (2000). Entrepreneurial spirit among east Asian Chinese. Thunderbird International Business Review, 42(3), 285-309.

5. Ariff, M., \& Abubakar, S. Y. (2002). Strengthening entrepreneurship in Malaysia. Malaysian Economic Outlook: 1st Quarter 2002 Update, 1-22.

6. Asian Development Bank (ADB), Asia Development Outlook 2002

7. Asian Development Bank (ADB), Poverty Reduction Strategy, 2002.

8. Autio, E., Kenney, M., Mustar, P., Siegel, D., \& Wright, M. (2014). Entrepreneurial innovation: The importance of context. Research Policy, 43(7), 1097-1108.

9. Bahrami, H., \& Evans, S. (1995). Flexible recycling and entrepreneurship. California Review, 37(3), 62-89.

10. Baumol, W. J., Litan, R. E., \& Schramm, C. J. (2007). Good capitalism, bad capitalism, and the economics of growth and prosperity.

11. Busenitz, L. W., \& Lau, C. M. (1996). A crosscultural cognitive model of new venture creation. Entrepreneurship:

Theory

and

Practice, 20(4), 25-40.

12. Chua, B. L. (2003). Entrepreneurship in Hong Kong: revitalizing entrepreneurship. In The Global Forum-Entrepreneurship in Asia: 4th US-Japan Dialogue, April (Vol. 16).

13. Cong J (2009) Chinese informal financial systems and economic growth: A case study of China's small and medium enterprises. Public Policy Review 5(1): 63-88.

14. Cook, Paul, "Finance and Small and MediumSized Enterprise in Developing Countries," Journal of Developmental Entrepreneurship, Vol. 6, Issue 1, Apr2001

15. Cummings, William K., "Asian values, education and development," Compare: A Journal of Comparative Education, Vol. 26, Issue 3, 1996.

16. Dana, Leo Paul, Entrepreneurship in Pacific Asia: Past, Present, and Future, Singapore: World Scientific, 1999.

17. Doshi, Kokila, "The rush to privatize in the AsiaPacific region," Business Forum, Vol. 19, Issue 1, 1994.

18. Drakopoulou Dodd, S., \& Anderson, A. R. (2007). Mumpsimus and the mything of the individualistic entrepreneur. International Small Business Journal, 25(4), 341-360.

19. Dubini, P. (1989). The influence of motivations and environment on business start-ups: Some hints for public policies. Journal of business venturing, 4(1), 11-26.

20. Edelman, B. (2014). GE Global Innovation Barometer, Global Report, 2014 Edition, GE,

21. El-Sokari, H., Van Horne, C. Huang, Z., \& AlAwad, M. (2013). Entrepreneurship. An Emirati Perspective, Abu Dhabi, Khalifa Fund for Enterprise Development \& Zayed University.

22. Fadahunsi, Olu, "Entrepreneurship and Small Industry Development in the Commonwealth," International Journal of Public Sector Management, Vol. 4, Issue 1, 1991.

23. Faria, J. R., Cuestas, J. C., \& Mourelle, E. (2010). Entrepreneurship and unemployment: A nonlinear bidirectional causality?. Economic Modelling, 27(5), 1282-1291.

24. Foster, G., Shimizu, C., Ciesinski, S., Davila, A., Hassan, S., Jia, N., \& Morris, R. (2013, September). Entrepreneurial ecosystems around the globe and company growth dynamics. In World Economic Forum (Vol. 11). 
25. GEM Thailand Report 2013 retrieved from $<$ https://summeruniversitythailand.org/ pdf/ 2013\% 20GEM\%20Thailand\%20Report.pdf $>$

26. Gomez, E. T., \& Hsiao, H. H. M. (2001). Introduction: Chinese business research in Southeast Asia. Chinese business in Southeast Asia: Contesting cultural explanations, researching entrepreneurship, 1-37.

27. Graham, Patricia \& Manning, Linda, "Women's Poverty and Entrepreneurship: Replicating Microloan Programs in the Developed World," Journal of Economics (Missouri), Vol. 26, Issue 2, 2000.

28. Herrington, M., \& Kew, P. (2017). GEM 2016/17 global report.

29. Imai, Y., \& Kawagoe, M. (2000). Business start-ups in Japan: problems and policies. Oxford Review of Economic Policy, 16(2), 114-123.

30. Kayed, R. N., \& Hassan, M. K. (2013). Islamic entrepreneurship. Routledge.

31. Kebaili, B., Al-Subyae, S. S., Al-Qahtani, F., \& Belkhamza, Z. (2015). An exploratory study of entrepreneurship barriers: the case of Qatar. World Journal of Entrepreneurship, Management and Sustainable Development, 11(3), 210-219.

32. Kuriakose, S. (Ed.). (2013). Fostering entrepreneurship in Georgia. World Bank Publications.

33. Lam, D., Paltiel, J. T., \& Shannon, J. H. (1994). The Confucian Entrepreneur? Chinese Culture, Industrial Organization, and Intellectual Property Piracy in Taiwan. Asian Affairs: An American Review, 20(4), 205-217.

34. Lau, C. M., \& Busenitz, L. W. (2001). Growth intentions of entrepreneurs in a transitional economy: The People's Republic of China. Entrepreneurship Theory and Practice, 26(1), 5-20.

35. Lee, J., \& Chan, J. (1998). Chinese entrepreneurship: a study in Singapore. Journal of management development, 17(2), 131-141.

36. Mariotti, Steve, "Solving the Poverty Problem," Executive Speeches, Vol. 13, Issue 5, 1999.

37. Mason, C., \& Brown, R. (2014). Entrepreneurial ecosystems and growth oriented entrepreneurship. Final Report to OECD, Paris, 30(1), 77-102

38. Organization for Economic Cooperation and Development (OECD), OECD Small and Medium Enterprise Outlook, 2000 Edition, OECD, 2000.

39. Owualah, Sunday, "Banks and Consultants in Nigeria's Job Creation Program," Small Business
Economics, Vol. 12, Issue 4, 1999.

40. Patra, Eleni, "National differences in entrepreneurial networking," Entrepreneurship \& Regional Development, Vol. 14, Issue 2, 2002.

41. Paulson, A. L. (2008). Financial Constraints and Entrepreneurship: Evidence from the Thai Financial Crisis: A Reprint from" Economic Perspectives". DIANE Publishing

42. Pennings, J. M. (1982). The urban quality of life and entrepreneurship. Academy of Management Journal, 25(1), 63-79.

43. Qatar National Development Strategy 2011 2016 https://www.mdps.gov.qa/en/nds/ Documents/ Downloads/NDS_EN_0.pdf

44. Qadir, Iqbal, "Unleash Your Entrepreneurs!" Newsweek, Dec., 1999

45. Redding, G. (1990). The spirit of Chinese capitalism (Vol. 22). Walter de Gruyter.

46. Reynolds BL (1982) Reform in Chinese industrial management: An empirical report. In: Joint Economic Committee, Congress of the United States (ed.) China under the Four Modernizations: Selected Papers, Part I. Washington, DC: U.S. Government Printing Office, pp.119-137.

47. Richardson, J. (2004). Entrepreneurship and development in Asia. International Journal of Entrepreneurship and Innovation Management, 4(5), 469-484.

48. Rudaz, P. (2012) . Entrepreneurship in Georgia.

49. Santhi, N., \& Kumar, S. R. (2011). Entrepreneurship Challenges and Opportunities in India. Bonfring International Journal of Industrial Engineering and Management Science, 1, 14.

50. Schramm, C. J. 2006a, "The Entrepreneurial Imperative: How American's Economic Miracle Will Reshape the World (and change your life), New York: HarperCollins.

51. Schwab, K. (ed) (2013). The Global Competitiveness Report 2013-2014: Full Data Edition, Geneva, World Economic Forum.

52. Shah, H. (2013). Creating an enabling environment for women's entrepreneurship in India. Development Papers, 1304.

53. Sorenson, O., \& Audia, P. G. (2000). The social structure of entrepreneurial activity: Geographic concentration of footwear production in the United States, 1940-1989. american Journal of Sociology, 106(2), 424-462.

54. Spulber, D. (2008). Entrepreneurs in the Theory of the Firm. Encontro anual AEA em Nova Orleans. 
55. Stam, E., \& Spigel, B. (2016). Entrepreneurial68. Yu, Tony Fu-Lai, "Adaptive entrepreneurship and Ecosystems and Regional Policy. 2016). Sage the economic development of Hong Kong," World Handbook for Entrepreneurship and Small Business: SAGE

56. Sunita, S., \& Srija, A. (2016). Entrepreneurship Development in India-the Focus on Startups. Laghu Udyog Samachar.

57. Tan, J. (1999). The growth of entrepreneurial firms in a transition economy: The case of a Chinese entrepreneur. Journal of Management Inquiry, 8(1), 83-89.

58. Tashiro, Y. (1999). Business angels in Japan. Venture Capital: An International Journal of Entrepreneurial Finance, 1(3), 259-273.

59. The Role of Government in Supporting Entrepreneurship \& SME Development"- by Mohammed Bin Rashid Establishment For SME Development DUBAI SME In 2011, https://www.oecd.org/ mena/competitiveness/47246782.pdf

60. Tracy, M. (2013). The State of Entrepreneurship in Turkey.

61. Tseng, C. C. (2012). Linking entrepreneurial infrastructures and new business development: Entrepreneurship development in Taiwan. The Journal of Entrepreneurship, 21(1), 117-132.

62. Ucbasaran, D., Westhead, P., \& Wright, M. (2001). The focus of entrepreneurial research: contextual and process issues. Entrepreneurship theory ${ }_{/}$and practice, 25(4), 57-80.

63. United Nations Development Program (UNDP), UNDP Human Development Report 2002, UNDP, 2002.

64. Van de Ven, H. (1993). The development of an infrastructure for entrepreneurship. Journal of Business venturing, 8(3), 211-230.

65. Vogel, P. (2013). The employment outlook for youth: building entrepreneurship ecosystems as a way forward. Isenberg, D. (2011). The entrepreneurship ecosystem strategy as a new paradigm for economic policy: Principles for cultivating entrepreneurship. Presentation at the Institute of International and European Affairs.

66. Welter, F. (2011). Contextualizing entrepreneurship - conceptual challenges and ways forward. Entrepreneurship theory and Practice, 35(1), 165-184.

67. Young MN, Peng MW, Ahlstrom D, Bruton GD and Jiang Y (2008). Corporate governance in emerging economies: A review of the PrincipalPrincipal perspective. Journal of Management Studies 45(1): 196-220. 